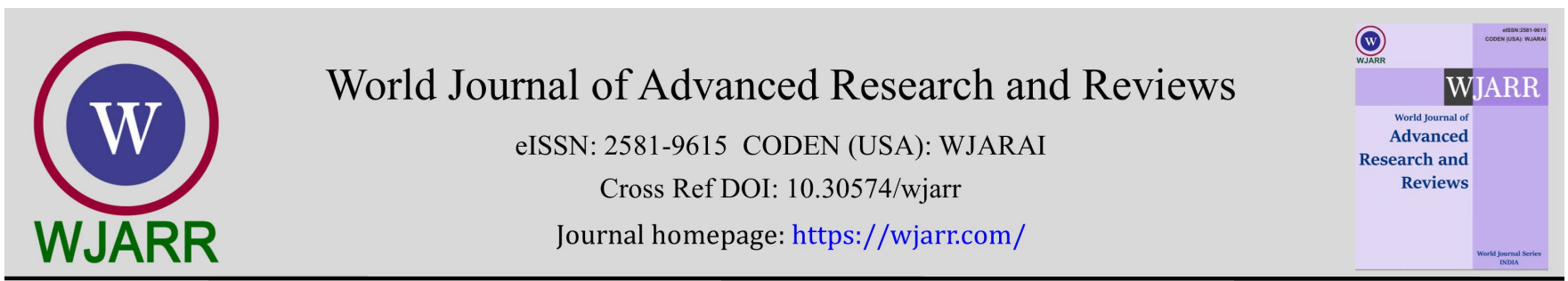

(RESEARCH ARTiClE)

Check for updates

\title{
Phytochemical screening, analgesic and anti-inflammatory activities from root extracts of Oligomeris linifolia
}

\author{
Khuram Ashfaq ${ }^{1,}{ }^{*}$, Muhammad Tariq ${ }^{2}$, M Abuzar Ghaffari ${ }^{3}$ and Sajid N Hussain ${ }^{3}$ \\ ${ }^{1}$ Department of pharmaceutical chemistry, Lahore Pharmacy College, Lahore, Pakistan. \\ 2 Department of pharmacology, Lahore Pharmacy College, Tulspura, Lahore, Pakistan. \\ ${ }^{3}$ Faculty of pharmacy, B.Z.U. Multan, Pakistan.
}

World Journal of Advanced Research and Reviews, 2021, 11(01), 215-220

Publication history: Received on 17 June 2021; revised on 26 July 2021; accepted on 28 July 2021

Article DOI: https://doi.org/10.30574/wjarr.2021.11.1.0335

\begin{abstract}
The present study evaluates the phytochemical screening, analgesic and anti-inflammatory properties of aqueous and methanolic extracts from the root of Oligomeris linifolia (OL). Pain responses were studied in mice using acetic acid writhing method and in rats using the hot plate and formalin test. The effect of the extract on edema induced by $1.5 \%$ carrageenan was also investigated. The extracts of OL exhibited significant anti-nocicetive properties against acetic acid induced abdominal constrictions in mice. In the rat the extract exhibited significant analgesic activity as evidence by (i) increased escaped latency on hot plate in the extract-treated rats and (ii) reduction in formalin-induced pain. The maximum edema rates attained in the rats pre-treated with $150 \mathrm{mg} / \mathrm{kg}$ of aqueous and methanol extracts of $0 \mathrm{~L}(12.50$ $\pm 2.88 \%, \mathrm{P}<0.005$ and $21.63 \pm 3.21 \%, \mathrm{P}<0.05$ respectively) were significantly lower than the control value $(32.62 \pm$ $5.33 \%)$. Aspirin $(150 \mathrm{mg} / \mathrm{kg})$ gave a maximum edema rate of $13.04 \pm 1.98 \%(\mathrm{P}<0.005)$. The results provide preliminary evidence for the anecdotal use of Oligomeris linifolia by traditional medical practitioners in the management of pain and inflammation.
\end{abstract}

Keywords: Oligomeris linifolia: Phytochemical; Analgesic; Anti-inflammatory

\section{Introduction}

Pain, disease and death have always been associated with the human life. The men of early ages must have used therapeutic agents from those things which were easily available to them. Plants were among those things which have used as remedies since time immemorial [1]. Infectious diseases are the leading cause of death world-wide. Antibiotic resistance has become a global concern [2]. The clinical efficacy of many existing antibiotics is being threatened by the emergence of multidrug-resistant pathogens [3]. Many infectious diseases have been known to be treated with herbal remedies throughout the history of mankind. Natural products, either as pure compounds or as standardized plant extracts, provide unlimited opportunities for new drug leads because of the unmatched availability of chemical diversity. There is a continuous and urgent need to discover new antimicrobial compounds with diverse chemical structures and novel mechanisms of action for new and re-emerging infectious diseases [4]. Therefore, researchers are increasingly turning their attention to folk medicine, looking for new leads to develop better drugs against microbial infections [5].

Resedaceae is family of 6 genera and 70 species found mostly in dry habitats in Africa, S. Europe, Middle Eeast, and Central Asia to SE. Asia and Eastern U.S.A". Oligomeris genus is with nine species distributed in SW. USA, N. \& S. Africa, Middle East to Pakistan and India. Represented locally by 1 species only [6].

\footnotetext{
* Corresponding author: Khuram Ashfaq

Department of pharmaceutical chemistry, Lahore Pharmacy College, Lahore, Pakistan.

Copyright $(2021$ Author(s) retain the copyright of this article. This article is published under the terms of the Creative Commons Attribution Liscense 4.0.
} 
Oligomeris linifolia (Vahl) (Rasedaceae) is one of four Oligomeris species, commonly named as lineleaf whitepuff. It is native to some parts of the Middle East India, Southern Europe, North Africa and North America. The plant grows in many habitat types including deserts, saline soils, plains, coastline, and other places. It is an annual herb, up to $50 \mathrm{~cm}$ tall, with a linear leaves and white flowers. [7].

\section{Material and methods}

The research work was carried out in natural product chemistry laboratory, Department of Pharmacy, Bahauddin Zakariya University, Multan. Description of materials and methods adopted is described below.

\subsection{Collection of Oligomeris linifolia}

The plant, Oligomeris linifolia was collected from forest park of Perrowal distric Khanewal. Dr. Altaf Hussain Dasti (Professor, Institute of pure and applied Biology, Bahauddin Zakariya University, and Multan) identified the plant as Oligomeris linifolia. The specimen voucher \# 38FCV1 was deposited in the herbarium of institute of pure and applied biology, Bahauddin Zakariya University, Multan.

\subsection{Extraction of Oligomeris linifolia}

For effective extraction of plant, whole plant material was kept under shade for drying for 15 days. When plant material dried, it was ground in grinding mill and weighed. The extraction of Oligomeris linifolia was carried out by simple maceration process. $350 \mathrm{gm}$ of ground plant material was taken in extraction bottle and measured volume of dichloromethane was added to it. To achieve maximum possible extraction, this mixture was shaken after some time then homogenized in ultrasonic bath. Filtration of this mixture was carried out after 24 hours. Then marc was macerated again by dichloromethane using same above procedure. After 3rd collection of this extract, the marc was extracted by methanol in the same manner. The extracts of dichloromethane and methanol were concentrated separately under reduced pressure by using rotary evaporator. The extracts of dichloromethane and methanol were collected in separate sample bottles and weighed. Then they were designated codes as OLD and OLM respectively.

\subsection{Preliminary phytochemical analysis}

Chemical tests are used for evaluation and identification of constituents in drug sample. These tests are very specific for a single compound or general for a specific class of constituents i.e., alkaloids. Color or turbidity is developed in many tests. Color should be matched with an authentic specimen while turbidity in sample tube, in case of precipitation reactions, is compared with reagent containing test tube alone. Mostly, these tests can equally be applied for extracts and isolated components [8].

\subsubsection{Tests for cardiac glycosides (Keller Kiliani test)}

$1 \mathrm{~g}$ of ground drug under study was taken in test tube and $10 \mathrm{ml}$ of $70 \%$ alcohol was added to it. Then mixture was boiled for 2 minutes on water-bath and filtered. Filtrate was diluted with double volume of distilled water and strong solution of lead sub acetate was added. Solution was filtered again that remove chlorophyll and other pigments. The filtrate was extracted with $10 \mathrm{ml}$ of chloroform or carbon tetrachloride after shaking it vigorously. Chloroform layer was separated and evaporated to dryness in a china dish over water bath. The residue was dissolved in $3 \mathrm{ml}$ of $3.5 \%$ ferric chloride in acetic acid glacial and transferred to test tube after one minute. Then sulfuric acid was added carefully along the wall of test tube which formed the lower layer. Cardiac glycosides were confirmed by appearing of pale green color at upper layer (due to steroidal nucleus) and Brown color at interface (due to deoxy sugar) on standing [9].

\subsubsection{Test for anthraquinones glycosides (Borntrager's test)}

$0.5 \mathrm{~g}$ of ground drug on study was taken and extracted with $10 \mathrm{ml}$ of hot water for 5 minutes. It was filtered while hot, allowed to cool and extracted with $10 \mathrm{ml}$ of carbon tetrachloride. The carbon tetrachloride was taken off, washed with $5 \mathrm{ml}$ of water and shaken with $5 \mathrm{ml}$ of dilute ammonia solution. No free anthraquinones were revealed as absence of color (pink to cherry-red). $0.1 \mathrm{~g}$ of other powdered drug was extracted with $10 \mathrm{ml}$ of ferric chloride solution and $5 \mathrm{ml}$ hydrochloric acid. It was heated on water bath for 10 minutes and filtered hot solution, then cool the filtrate and subsequently extracted with $10 \mathrm{ml}$ of carbon tetrachloride. The carbon tetrachloride was taken off, washed with $5 \mathrm{ml}$ of water and shaken with $5 \mathrm{ml}$ of dilute ammonia solution. No anthraquinone glycosides were revealed as absence of color (intense pink to cherry-red) in drug under study [10].

\subsubsection{Tests for saponin glycosides}

$0.5 \mathrm{~g}$ of powdered drug was added to water. Persistent froth was formed which indicated presence of saponins [11]. 


\subsubsection{Tests for alkaloids}

$3 \mathrm{~g}$ of powdered drug under study was taken and boiled with $10 \mathrm{ml}$ of dilute $\mathrm{HCl}$ in a test tube for 1 minute then cool and allow the debris to settle. Supernatant liquid was poured off other test tube. 3 drops of Dragendorff's reagent were added to $1 \mathrm{ml}$ of filtrate. The distinct precipitate or turbidity appeared that indicate presence of alkaloids. To further confirm the presence of alkaloids, the remainder of the filtrate was made alkaline to litmus paper with dilute ammonia solution. This alkalinized solution was transferred to separating funnel and extracted with $5 \mathrm{ml}$ of chloroform by shaking it gently. Two layers were observed. The lower chloroform layer was extracted with $10 \mathrm{ml}$ of dilute acetic acid and discarded the chloroform. The extract was divided into four portions and adds few drops of Wagner's reagent, Mayer's reagent and Dragendorff's reagent to three portions separately. An observation of turbidity or precipitate compared with untreated control (fourth portion) with either or all reagents confirmed presence of alkaloids [12].

\section{Animals}

Adult male Swiss mice $(20-25 \mathrm{~g})$ and Wistar strain albino rats $(110-150 \mathrm{~g})$ obtained from the small animal house, department of Pharmacology were used. They were caged under standard laboratory conditions and fed with laboratory animal cubes and water ad libitum. Acclimatization period of two weeks was allowed (housing condition: $27 \pm 2^{\circ} \mathrm{C}$ ) before the commencement of the study.

\subsubsection{Tests for Analgesic activities}

Acetic acid - induced abdominal writhing test

Mice were treated orally with aqueous (AES) and methanol (MES) extracts of OL at 17.5, 35.0, 70.0, and 140mg/kg doses. Acetylsalicylic acid (Aspirin) was used as a reference analgesic compound at similar doses as AES and MES. Control animals received $0.2 \mathrm{ml}$-distilled water. 30 minutes later, the animals were given $1.2-\%$ acetic acid solution intraperitoneally. Each animal was observed during 15min. of acetic acid injection. The symptoms of the acetic acidinduced abdominal writhing were similar to those described by Emele and Shanaman (1963). The number of writhing and stretching within the observation period was recorded. The percentage protection was calculated using the ratio: (control mean -treated mean) x 100/control mean [13].

\subsubsection{Hot Plate assay}

This was achieved by a minor modification of the method described by Woofe and MacDonald (1944). The hot plate was standardized by inverting a water-filled conical flask, which was connected by rubber tubing to water through. The temperature of the inverted flask was kept constant at $56 \pm 1{ }^{\circ} \mathrm{C}$ by a cyclotherm inserted into the through. The reaction time (time taken by the animal to lick or fan its paws or jump from the plate) was measured and recorded 30 minutes prior to oral administration of AES, MES, reference drug or vehicle and at 30,50, 70 and 90 minutes after administration. The percentage increase in reaction time over control latencies for each drug group was calculated from the mean latency before drug administration.

Each animal served as its own control, as preliminary experiments showed that the procedure involved with the oral administration of the vehicle alone had no significant effect on the response times at 90 minutes.

\subsubsection{Formalin test}

Rats were treated orally with AES at vehicle animals were observed for 60 minutes after a subplantar injection of $0.05 \mathrm{ml}$ of sterile 5\% formalin. The pain rating scale of Dubuisson and Dennis (1977) was essentially followed.

\subsubsection{Anti-inflammatory tests}

Carrageenan-induced paw edema-An Edema was induced on the right foot of rats by subplantar injection of $0.05 \mathrm{ml}$ of solution of $1.5 \%$ carrageenan in $0.9 \%$ saline $(\mathrm{w} / \mathrm{v})$. The diameter of the injected paws and contra lateral paws were measured 1 hour before and 1,2,3,4 and 5 hours after induction of inflammation using a cotton thread. The edema was expressed in terms of the difference between the right and left B paws. The reference group of animals were treated with Aspirin (120mg/kg).

\subsubsection{Statistical analysis}

For the experiments on formalin, carrageenan paw edema and acid writhing tests, statistical comparisons were made using the Student's t-test. For the hot plate test, paired t- test was used to compare results of pain responses before and after treatment with extract, reference drug or vehicle. 


\section{Results}

\subsection{Secondary Metabolites}

The results of detection of secondary metabolites root extracts of Oligomeris linifolia are shown in table below 1.

Table 1 Result of secondary metabolites in root extract of Oligomeris linifolia

\begin{tabular}{|l|l|l|l|l|}
\hline Plant name & Alkaloids & Anthraquinones & Cardiac glycosides & Saponins \\
\hline Oligomeris linifolia & Absent & Present & Present & Present \\
\hline
\end{tabular}

\subsection{Analgesic activity}

\subsubsection{Acetic acid writhing response}

The cumulative dose-response relationship for the anti-nociceptive property of AES using the acetic acid writhing model is shown in Fig.1. At a dose of $17.5 \mathrm{mg} / \mathrm{kg}$ the aqueous and methanol extracts gave $38.47 \%(\mathrm{P}<0.05)$ and $27.63 \%(\mathrm{P}<$ 0.05 ) protection respectively while the protections at $140 \mathrm{mg} / \mathrm{kg}$ were $68.78 \%$ and $55.60 \%$ respectively $(\mathrm{P}<0.001)$. The respective doses of AES and MES necessary to give 50\% protection against acetic acid induced pain (PD50 obtained by regression analysis using the dose-response relationship) were $44.46 \mathrm{mg} / \mathrm{kg}$ and $77.6 \%$. Aspirin, which was used as the reference analgesic drug, gave a PD50 of $65.38 \mathrm{mg} / \mathrm{kg}$.

\subsection{Hot Plate test}

As shown in Table 2, the animals treated with both aqueous and methanol extract of OL tolerated the hot plate to significantly higher levels than those given vehicle. The maximum inhibitory rates of MES and AES (150mg/kg) and aspirin $(150 \mathrm{mg} / \mathrm{kg}$ as positive control) were $35.98 \pm 3.22,49.744 .25$ and $28.65 \pm 3.20$ respectively.

Table 2 Effect of aqueous (AES) and methanol (MES) root extracts of Oligomeris linifolia on thermal (hot plate) induced pain in mice

\begin{tabular}{|c|c|c|c|c|c|c|c|}
\hline \multirow[t]{2}{*}{ Treatment } & \multirow[t]{2}{*}{ Tolerance } & \multirow{2}{*}{$\begin{array}{l}\text { Pre- } \\
\text { treatment }\end{array}$} & \multicolumn{5}{|c|}{ Post-treatment } \\
\hline & & & $30 \mathrm{~min}$ & $50 \mathrm{~min}$ & $70 \mathrm{~min}$ & & $\operatorname{lin}$ \\
\hline \multirow[t]{2}{*}{ Vehicle } & Latency (min) & $9.95 \pm 0.87$ & $10.2 \pm 0.6$ & $8.7 \pm 1.07$ & $9.55 \pm 1.01$ & 11.05 & \pm 3.8 \\
\hline & Protection (\%) & 0 & $2.51 \pm 0.34$ & $12.56 \pm 0.26$ & $4.02 \pm 0.33$ & 11.06 & \pm 0.62 \\
\hline \multirow[t]{2}{*}{ MES } & Latency (min) & $10.2 \pm 1.65$ & $12.46 \pm 0.95$ & $13.87 \pm 0.92$ & $11.9 \pm 0.78$ & 10.81 & \pm 1.10 \\
\hline & Protection (\%) & 0 & $22.16 \pm 4.12$ & $35.98 \pm 3.72$ & $16.67 \pm 2.68$ & 21.62 & \pm 2.2 \\
\hline \multirow[t]{2}{*}{ AES } & Latency (min) & & $13.18 \pm 0.98$ & $14.3 \pm 0.71$ & $12.25 \pm 0.85$ & 11.07 & \pm 0.74 \\
\hline & Protection (\%) & 0 & $37.96 \pm 5.35$ & $49.74 \pm 4.25$ & $28.27 \pm 2.93$ & 15.92 & \pm 4.06 \\
\hline \multirow[t]{2}{*}{ Aspirin } & Latency (min) & & $11.91 \pm 0.94$ & $12.17 \pm 1.08$ & $11.98 \pm 0.97$ & 11.84 & \pm 0.92 \\
\hline & Protection (\%) & 0 & $26.37 \pm 4.13$ & $28.65 \pm 3.20$ & $27.06 \pm 4.02$ & 25.62 & \pm 3.25 \\
\hline
\end{tabular}

\subsubsection{Formalin test}

The pain scores of controls and extract-treated rats after subplantar injection of formalin are shown in fig. 3. Both extracts of OL inhibited both the early and late phases of formalin-induced pain response. The reference algic drug, aspirin, inhibited only the late phase. The mean pain scores in the rats treated with MES, AES and aspirin $(150 \mathrm{mg} / \mathrm{kg})$ were 1.66 $\pm 0.11(\mathrm{P}<0.05), 1.23 \pm 0.15(\mathrm{P}<0.01)$ and $1.33 \pm 0.19(\mathrm{P}<0.02)$ respectively when compared with the vehicle treated control animals $(1.87 \pm 0.12)$. 


\subsubsection{Anti-inflammatory test}

The maximum edema rates attained in the rats pre- treated with MES and AES $(21.68 \pm 3.21, \mathrm{P}<0.05$ and $12.50 \pm 2.88$, $\mathrm{P}<0.05$ respectively) were significantly lower than the control value $(32.62 \pm 5.33 \%)$. Aspirin $(150 \mathrm{mg} / \mathrm{kg})$ gave a maximum edema rate of $13.04 \pm 1.98 \%(\mathrm{P}<0.01)$.

Table 3 Effect of aqueous (AES) and methanol (MES) root extracts of Oligomeris linifolia on carragenan-induced paw edema at $3 \mathrm{hrs}$

\begin{tabular}{|l|c|c|c|c|}
\hline & Vehicle & AES & MES & Aspirin \\
\hline Mean Paw Edema (cm) & $3.2 \pm 0.06$ & $2.5 \pm 0.38^{* *}$ & $2.88 \pm 0.04$ & $2.60 \pm 0.05^{*}$ \\
\hline \% Inhibition & 10.34 & 57.52 & 10.3 & 51.47 \\
\hline
\end{tabular}

\section{Discussion}

The methanol and aqueous extract of Oligomeris linifolia has been screened for analgesic and anti-inflammatory activities. The major reason for performing the study was to confirm the anecdotal evidence that the plant can be used in the treatment of pain-related conditions [14].

Several chemicals (e.g. Phenylquinone, acetic acid e.t.c) have been reported to induce writhing responses in animals (Berkenkopt and Weichman, 1988). In the present study, aqueous extract in OL inhibited the writhing responses induced by acetic acid in a dose-dependent manner, the potency being greater than that of the references analgesic compound, aspirin. The PD50 of $66.07 \mathrm{mg} / \mathrm{kg}$ obtained for our brand of acetyl salicyclic acid in the present study compared favourably with a previously reported value of $68.0 \mathrm{mg} / \mathrm{kg}$ for the same compound and using the same painrating method. A major setback of the acetic acid writhing method is its inability to indicate whether the analgesic effect way due to central or peripheral inhibitions [15].

Thermal induced nociceptive responses could be inhibited by centrally acting analgesics (e.g. narcotic agents) but not peripheral analgesics like aminopyrine or aspirin [16]. Hence the poor inhibitory response of aspirin in the hot plate assay. Our results suggest that OL may have a central analgesic effect. This assertion is further supported by the result of the formalin test, which has been a useful tool for obtaining neurogenic inflammation and continuous pain.

The biphasic reaction of carrageenan induced and paw edema has been reported. The early phase of the inflammation was related to the release of histamine and like substances while the late phase was associated with the activation of plama kinnins and tissue prostaglandins. OL in the present study inhibited the early phase of the carrageenan-induced paw edema. Many plant extracts containing saponins, glycosides and tannins as the major active components have been shown to have potent analgesic properties $[17,18]$. The activities OL reported the present study and may not be unrelated to the presence of these compounds.

Further studies concerning the isolation and pharmacology of the active substances are warranted.

\section{Conclusion}

The findings of the study validate the traditional use of selected medicinal plant for the management of pain and inflammation. Further investigation for the isolation of secondary metabolites responsible for pharmacological activities, is suggested.

\section{Compliance with ethical standards}

\section{Acknowledgments}

Author is thankful to staff of animal house for providing assistance.

\section{Disclosure of conflict of interest}

There is no conflict of interest among authors. 


\section{References}

[1] Kappos AD, Bruckmann P, Eikmann T, Englert N, Heinrich U, Höppe P, Koch E, Krause GH, Kreyling WG, Rauchfuss $\mathrm{K}$, Rombout P. Health effects of particles in ambient air. International journal of hygiene and environmental health. 1 sep 2004; 207(4): 399-407.

[2] Westh H, Zinn CS, Rosdahl VT, Sarisa Study Group. An international multicenter study of antimicrobial consumption and resistance in Staphylococcus aureus isolates from 15 hospitals in 14 countries. Microbial drug resistance. 1 jun 2004; 10(2): 169-76.

[3] Bandow JE, Brötz H, Leichert LI, Labischinski H, Hecker M. Proteomic approach to understanding antibiotic action. Antimicrobial agents and chemotherapy. 1 Mar 2003; 47(3): 948-55.

[4] Rojas R, Bustamante B, Bauer J, Fernández I, Albán J, Lock O. Antimicrobial activity of selected Peruvian medicinal plants. Journal of ethnopharmacology. 1 Oct 2003; 88(2-3): 199-204.

[5] Oladele AC, Olumayowa AA, Temitope OS. Phytochemical and antimicrobial activity of ethnomedicinal leaf extract of selected plants in Nigeria. World Journal of Advanced Research and Reviews. 2020; 7(1): 253-62.

[6] Ali SI. Papilionaceae In: Flora of Pakistan. (Eds.): E. Nasir \& SI Ali. 1977; (100).

[7] El-Hagrassy AM, Elkhateeb A, Hussein SR, Abdel-Hameed ES, Marzouk MM. LC-ESI-MS profile, antioxidant activity and cytotoxic screening of Oligomeris linifolia (Vahl) Macbr. (Resedaceae). Journal of Applied Pharmaceutical Science. Aug 2017; $7(8):$ 43-7.

[8] Musa KY, Katsayal AU, Ahmed A, Mohammed Z, Danmalam UH. Pharmacognostic investigation of the leaves of Gisekia pharnacioides. African Journal of Biotechnology. 2006; 5(10).

[9] Abdullahi MN, Ilyas N, Ibrahim H. Evaluation of phytochemical screening and analgesic activity of aqueous extract of the leaves of Microtrichia perotitii Dc (Asteraceae) in mice using hotplate method. Medicinal Plant Research. 21 Mar 2013; 3(5).

[10] De S, Dey YN, Ghosh AK. Phytochemical investigation and chromatographic evaluation of the different extracts of tuber of Amorphaphallus paeoniifolius (Araceae). Int J Pharm Biol Res. 2010; 1(5): 150-7.

[11] Zahro L, Agustini R. Uji Efektivitas Antibakteri Ekstrak Kasar Saponin Jamur Tiram Putih (Pleurotus Ostreatus) Terhadap Staphylococcus Aureus Dan Escherichia Coli Antibacterial Effectivity Test Of Saponins Crude Extract From White Oyster Mushroom (Pleurotus Ostreatus) Against. UNESA Journal of Chemistry. 25 Sep 2013; 2(3).

[12] Hussain HS, Deeni YY. Plants in Kano ethnomedicine; screening for antimicrobial activity and alkaloids. International Journal of Pharmacognosy. 1 Jan 1991; 29(1): 51-6.

[13] Baghdikjan B, Lanhers MC, Fleurentin J, 011ivier B, Maillard C, Balansard G, Mother F. An analytical study, antiinflammatory and analgesic effects of Hrpagophytwn procumbens and Harpagophytum zeyheri: Planta Medica. 1997; 63: 171-176.

[14] Akinniyi JA, Suanbawa US. A Glossary of Kanuri names of plants with botanical names, distribution and uses. Annals of Borno. 1983; 1: 85-98.

[15] Chen YF, Tsai HY, Wu TS. Anti-inflammatory and analgesic activities from roots of Angelical puhescens. Plants Med. 1995; 6(1): 2-8.

[16] Woolfe G, Macdonald AD. The evaluation of the analgesic action of pethidine hydrochloride. (Demerol). J. Pha amacoL Expt. Ther. 1944; 80: 300-307.

[17] Gene RM, Cartana G, Adzet T, Mann B, Parella T, Canigucral S. Antiinflammatory and analgesic activity of Baccharis trimera: identification of its active constituents. Planta Medical. 1996; 62(3): 232-5.

[18] MIGUEL 00, Calixto JB, Santos AR, Messana L, Ferrari F, Cechinet FV, Pizzolatti MC, Yunes RA. Chemical and preliminary analgesic evaluation of geranin and furosin isolated from Phyllanthus sellowianus. Planta Medica. 1996; 62(2): 146-9. 